\title{
Marketing Aspects of Discount Airlines in the Russian Market
}

${ }^{1}$ Lilijana A. Sosunova, ${ }^{2}$ Dana V. Chernova, ${ }^{3}$ Lyubov N. Semerkova

${ }^{4}$ Irina A. Toymentseva, ${ }^{* 5}$ Kristina P. Syrova

${ }^{1}$ Professor, Head of the Department of Marketing, Logistics and Advertising, Samara State University of Economics

${ }^{2}$ Professor, Director of the Institute of Commerce, Marketing and Service, Samara State University of Economics

${ }^{3}$ Professor, Head of the Department of Marketing, Commerce and Service, Penza State University

${ }^{4}$ Professor, Department of Marketing, Logistics and Advertising, Samara State University of Economics

${ }^{*}$ Post-Graduate Student, Samara State University of Economics, Russian Federation



\section{Received: $1^{\text {st }}$ April 2018, Accepted: 23 $^{\text {rd }}$ May 2018, Published: 30 $^{\text {th }}$ June 2018}

\begin{abstract}
The urgency of the research is caused by the changes that have taken place in the Russian civil aviation industry, the strategy of which is aimed at consolidating the industry, and as a consequence, at changing the market structure for passenger air travel. To increase the competitiveness of the Russian civil aviation industry, it is necessary to improve production activities and introduce new business models for the Russian market, in particular, the model of discount airlines. The purpose of the article is to analyze and identify the reasons for the failure of business models of Russian discount carriers operating earlier. The leading approach to the study of this problem is the logical-theoretical research method. Using this approach, the authors analyze the failed business plans of previously operating Russian discount air carriers such as Avianova, SkyExpress, Pobeda and the main barriers to the development of the discount airline industry in Russia and the main marketing aspects of discount airlines performance on the Russian market. The materials of this article can be useful for airlines or a group of airlines that seek to develop the share on both the Russian and global markets in the passenger air transportation industry, for example, such enterprises as PJSC Aeroflot and PJSC S7.
\end{abstract}

Keywords: Airline, Discount Air Carrier, Competition, Competitiveness, Low-Cost Airline, Airline Marketing.

\section{Introduction}

Over the past five years, the Russian market of air passenger transport has undergone significant changes. In addition to the quantitative growth of passenger traffic in the industry, significant qualitative changes have taken place. Consolidation in the industry, changes in airport management, increased state attention to the development of domestic tourism, as well as the withdrawal of Transaero from the market, that was one the main player in the airline industry, have become key trends in the Russian aviation market over the past five years. To increase

competitiveness, Russian airlines need to seek and apply both new methods of marketing communications, new approaches in organizing the logistics service, and introduce new business models in general. "Discount air carrier", as one of the youngest management models of air travel, is rapidly increasing its share in the markets of Europe and the US, but it is hard to get accustomed to in the Russian Federation. The goal of this research is the insolvency and the collapse of the discount airline model in the Russian market on the basis of previous experience of Russian carriers.

\section{Brief Literature Review}

Previously, the competitiveness of Russian airlines was considered in the works of many authors, in particular in the research work of E.V. Veselova: "Competitiveness of Russian Airlines in International Markets of Passenger Air Transportation" (Veselova, 2015) [1], in the work of I.G. Fedyashova: "Marketing Research of Airport Services" (Fedyashova, 2006) [2], in the work of I. A. Belavintsev "State Support of Passenger Air Transportation on Domestic Airways" (Belavintsev, 2012) [3]. The problem of logistics services and the use of this concept at enterprises of various industries have been studied in the works of many Russian authors, in particular in the research work of A.V. Klyagin: "Logistics Services in Activities of University of Economics" (Klyagin, 2006) [4], as well as in the work of "Management of Logistics Services in Activities of Car Dealers" (Yaguzinskaya, 2014) [5]. In the foreign literature, these issues were considered in the works of such researchers as Hazledine: "PRICE DISCRIMINATION, MERGER POLICY, AND THE COMPETITIVE CONSTRAINT OF LOW-VALUE CUSTOMERS IN AIRLINE MARKETS" (Hazledine, 2015) [6], "Market segmentation of airline cargo transport" (Ching-Cheng Chao, Taih-Cherng Lirn \& Kuo-Chung Shang, 2013) [7], “An airline's 
management strategies in a competitive air transport market" (Young Dae Ko,2016) [8].

Despite the high level of scientific work of the abovementioned researchers, it should be noted that the marketing and logistics services of discount airlines in the passenger air transportation industry in the Russian market have not been adequately researched and developed. These facts have predetermined the goal of this research work. The main goal of this article is to identify the factors that affect the performance of discount airlines in Russia, to minimize the risks of these enterprises in the future.

\section{Methodology}

The authors use the method of scientific abstraction, which "separates" the target of research from randomness and allows determining the typical and constant characteristics of the goal of research. Since the goal of this research is the business model of discount airlines, as a result, the main factors of influence on the companies' performance in the Russian market should be identified. In addition, as these factors in the process of research can be identified by cause-effect relationship existing between the business model of airlines, discounters and features of the Russian economy.

To identify the most significant factors affecting the successful operation of discount airlines, the authors consider the world experience of successful airlines in this industry and conduct a comparative analysis of their business models. The following discount airlines will be considered: the American airline Southwest, the Irish company Ryanair, the British airline EasyJet, as well as the airline FlyDubai.

The authors carry out the comparative analysis of the data of the airlines performing under the low-cost airline business model in Table 1 .
Table 1 shows the main distinctive features of the most successful discounters for today, whose successful performance is measured by the indicators of the volume of their passenger flow for the last three years. Thus, the following distinctive features of their business models are common for successful discounters in the world market:

1. The use of a single aircraft type.

2. The average age of the aircraft depot is up to 10 years.

3. One class of service: economy class.

4. No connecting flights.

5. Possibility to purchase tickets only through the official website of the airline.

6. Impossibility of refunding tickets.

7. Proposal of additional services for customers: paid seat assignment in the cabin, paid luggage transportation, paid meals on board.

The authors analyze whether discount airlines have these distinctive features which already existed in this or that time period in the Russian economy. To do this, the authors compare airlines Avianova, SkyExpress, Pobeda by main "success factors" revealed in the review of the world's airlines. The data are given in Table 2.

Based on the information presented in Table 1, it can be concluded that the main factors affecting the successful performance of discount airlines were not observed by the low-cost airlines that existed in the Russian Federation before, and the only operating low-cost airline Pobeda has a relatively low share in the total volume of passenger flow in Russia.

Tab. 1: The Distinctive Features of Airlines Southwest, Ryanair, EasyJet, FlyDubai

\begin{tabular}{|c|c|c|c|c|c|c|}
\hline \multirow{2}{*}{ Airline } & \multicolumn{3}{|c|}{ Passenger flow, million people } & \multirow{2}{*}{$\begin{array}{l}\text { Year of } \\
\text { foundation, } \\
\text { country }\end{array}$} & \multirow{2}{*}{$\begin{array}{l}\text { Number of } \\
\text { aircrafts }\end{array}$} & \multirow{2}{*}{$\begin{array}{l}\text { Types of } \\
\text { aircrafts }\end{array}$} \\
\hline & 2015 & 2016 & 2017 & & & \\
\hline Southwest & 134,1 & 151,8 & $\mathrm{n} / \mathrm{a}$ & 1971, USA & 723 & Boeing 737 \\
\hline Ryanair & 95 & 110 & 122 & 1985, Ireland & 372 & $\begin{array}{l}\text { Boeing 737- } \\
800\end{array}$ \\
\hline EasyJet & 64,8 & 73,1 & $\mathrm{n} / \mathrm{a}$ & 1995, England & 254 & $\begin{array}{l}\text { Airbus A319 } \\
\text { and A320 }\end{array}$ \\
\hline Fly Dudai & 9,04 & 10,4 & $\mathrm{n} / \mathrm{a}$ & 2009, UAE & 61 & $\begin{array}{l}\text { Boeing 737- } \\
800\end{array}$ \\
\hline
\end{tabular}


Helix Vol. 8(4): 3448- 3453

\begin{tabular}{|l|l|l|l|l|l|l|}
\hline & \multirow{2}{*}{$\begin{array}{l}\text { Average age } \\
\text { of the aircraft } \\
\text { depot }\end{array}$} & $\begin{array}{l}\text { Route network, } \\
\text { number of } \\
\text { directions }\end{array}$ & $\begin{array}{l}\text { Connecting } \\
\text { flights }\end{array}$ & Service class & Official site & Sales office \\
\cline { 7 - 9 } & 11,7 years & 97 & $\mathrm{n} / \mathrm{a}$ & economy class & available & $\mathrm{n} / \mathrm{a}$ \\
\hline Southwest & 6,5 years & 192 & $\mathrm{n} / \mathrm{a}$ & economy class & available & $\mathrm{n} / \mathrm{a}$ \\
\hline Eyanair & 7,5 years & 134 & available & economy class & available & $\mathrm{n} / \mathrm{a}$ \\
\hline Fly Dudai & 3,7 years & 85 & n/a & $\begin{array}{l}\text { business and } \\
\text { economy class }\end{array}$ & available & $\mathrm{n} / \mathrm{a}$ \\
\hline
\end{tabular}

\begin{tabular}{|c|c|c|c|c|c|c|}
\hline Airlines & $\begin{array}{l}\text { Refunding } \\
\text { tickets }\end{array}$ & $\begin{array}{l}\text { Seat } \\
\text { assignment }\end{array}$ & $\begin{array}{l}\text { Luggage } \\
\text { transportation }\end{array}$ & Meals on board & $\begin{array}{l}\text { Bonus } \\
\text { system }\end{array}$ & $\begin{array}{l}\text { The share of } \\
\text { additional } \\
\text { services in } \\
\text { total profit }\end{array}$ \\
\hline Southwest & $\mathrm{n} / \mathrm{a}$ & paid & paid & paid & $\begin{array}{c}\text { availableRa } \\
\text { pid } \\
\text { Rewards }\end{array}$ & $\mathrm{n} / \mathrm{a}$ \\
\hline Ryanair & $\mathrm{n} / \mathrm{a}$ & paid & paid & paid & $\mathrm{n} / \mathrm{a}$ & $20 \%$ \\
\hline EasyJet & $\mathrm{n} / \mathrm{a}$ & paid & paid & paid & $\begin{array}{c}\text { availableEa } \\
\text { syJet plus }\end{array}$ & $\mathrm{n} / \mathrm{a}$ \\
\hline Fly Dudai & $\begin{array}{l}\text { In business } \\
\text { class, } \\
\text { exchange for } \\
\text { a voucher }\end{array}$ & $\begin{array}{c}\text { paid } \\
\text { only in } \\
\text { economy class }\end{array}$ & $\begin{array}{c}\text { paid } \\
\text { only in economy } \\
\text { class }\end{array}$ & $\begin{array}{c}\text { paid } \\
\text { only in } \\
\text { economy class }\end{array}$ & $\begin{array}{l}\text { availableO } \\
\text { PEN }\end{array}$ & $14 \%$ \\
\hline
\end{tabular}

Tab. 2: Distinctive Features of Airlines SkyExpress, Avianova, Pobeda

\begin{tabular}{|c|c|c|c|c|c|c|}
\hline \multirow{2}{*}{ Airlines } & \multicolumn{3}{|c|}{ Passenger flow, million people } & \multirow{2}{*}{ Year of foundation } & \multirow{2}{*}{$\begin{array}{l}\text { Number } \\
\text { aircrafts }\end{array}$} & \multirow{2}{*}{$\begin{array}{l}\text { Types } \\
\text { aircrafts }\end{array}$} \\
\hline & $1 "$ & $2 "$ & 3" & & & \\
\hline SkyExpress & 2007: 0,679 & 2008: 1,041 & 2009: 1,109 & $\begin{array}{l}\text { 2006-2011 } \\
\text { Vnukovo }\end{array}$ & 14 & Boeing 737 \\
\hline Avianova & 2009: 0,4 & 2010: 1,2 & $\mathrm{n} / \mathrm{a}$ & $\begin{array}{l}\text { 2009-2011 } \\
\text { Sheremetyevo }\end{array}$ & 6 & Airbus A320 \\
\hline $\begin{array}{l}\text { Pobeda } \\
\text { (Information } \\
\text { Agency of } \\
\text { RBC, 2016) [9] }\end{array}$ & $2015: 3,1$ & 2016: 4,3 & 2017: 5,1 & $\begin{array}{l}2014 \\
\text { Vnukovo }\end{array}$ & 16 & Boeing 737-800 \\
\hline Airlines & $\begin{array}{l}\text { Route } \\
\text { network, } \\
\text { number of } \\
\text { directions }\end{array}$ & $\begin{array}{l}\text { Average } \\
\text { age of the } \\
\text { aircraft } \\
\text { depot }\end{array}$ & $\begin{array}{l}\text { Single } \\
\text { service } \\
\text { class: }\end{array}$ & Connecting flights & $\begin{array}{l}\text { Purchasing } \\
\text { tickets via the } \\
\text { official site }\end{array}$ & $\begin{array}{l}\text { Additional } \\
\text { services }\end{array}$ \\
\hline
\end{tabular}


Helix Vol. 8(4): 3448- 3453

\begin{tabular}{|l|l|l|l|c|l|c|}
\hline & & $\begin{array}{l}\text { economy } \\
\text { class }\end{array}$ & & \\
\hline SkyExpress & 13 & 19 years & available & $\mathrm{n} / \mathrm{a}$ & available & available \\
\hline Avianova & 23 & 9 years & available & $\mathrm{n} / \mathrm{a}$ & available & available \\
\hline Pobeda & 26 & 2,9 years & available & available & available & available \\
\hline
\end{tabular}

Source: Federal Air Transport Agency of the Russian Federation. Rosaviation. (2016) [10]

\section{Results}

In addition to the factors identified above, which affect the expansion of the Russian market for low-cost air transportation, there are also a number of problems that have not been solved in the legal and economic spheres. High import duties on foreign equipment, lack of highly qualified pilots (commanders of crews), impossibility to introduce a ticket non-return rule, congestion of airports are barriers to reduce costs and expand air travel in Russia before the adoption of changes in Russian legislation.

The lack of highly qualified pilots has already been resolved by amending Article 56 of the Air Code, which until April 2014 provided the possibility of including a foreign citizen in the flight crew only on condition that the foreign citizen does not perform the duties of the commander of the aircraft of the Russian Federation. Adoption of the Federal Law of April 20, 2014 No. 73-FZ [11] granted the right to legal entities and individual entrepreneurs performing commercial air transportations to conclude the employment contract with a foreign citizen to replace the post of commander of a civil aircraft for a period of five years. One of the factors that significantly increased the costs of airlines was the impossibility of concluding sales contracts on non-refund tickets. According to the Ministry of Transport, airline losses from ticket refund amounted to about 30 billion rubles a year. Amendments to Articles 107 and 108 of the Air Code, introduced by Federal Law No. 79-FZ of April 20, [11] granted companies the right to conclude such contracts Many experts believe that for the effective operation of the discount airline in the Russian market, it is necessary to solve a complex of tasks. The core of the problem is the lack of the infrastructure for discount airlines in Russia. Is it possible that Aeroflot operates in Sheremetyevo next to the discounter? Or is it possible to operate with the "S7" in Moscow's Domodedovo? (S7 Airlines, 2016) [12] In order to obtain excellent figures and high passenger flow from the discount airline it is necessary to create the following condition: secondary airports are built in cities with a million population and they are loaded less than basic ones. So, this approach allows successful European discount airline "Ryanair", "EasyJet" to organize flights to Europe, Africa at lower costs.

For the optimal performance of low-cost airlines in the vast territory of Russia, it is necessary to analyze the activities of a particular discount airline. For example, it may be the airline specializing only in flights in the European, the southern, or Far Eastern parts of the country, or in Siberia, perhaps there will be a more local division of the zones of low-cost airlines' activity. This will help to reduce the dependence of airlines on weather conditions of the airport's departure and arrival, which often, due to the climatic conditions of Russia, lead to delays in flights, unreadiness of airports, air parks, personnel, etc.

Zoning can have a positive effect on the company's pricing and marketing policies. Taking into account the scale of the Russian territory, it is impossible to reduce the cost of flight from the European part of Russia as it is impossible to fly from Moscow to Khabarovsk even on new Boeing 737 aircraft. If the air travel is more than $6000 \mathrm{~km}$, neither the rule of flight within one continent, nor the point-to-point approach, nor the presence of secondary airports and other requirements of the classic low-cost model will allow the route to be inserted on the flight map when organizing a flight to Boeing 737 , since the technical characteristics of the aircraft of this model are designed for a maximum flight range of $5500 \mathrm{~km}$. Accordingly, when flying from Moscow to Khabarovsk it is necessary to solve one of two tasks: refueling during the flight or buying aircrafts "Boeing 777 " or "Airbus A330", which are more expensive in maintenance, and, as a result, the price of air tickets will be higher for passengers. So, in this case this problem can be solved by zoning.

Summing up, it can be concluded that this research work analyzes business models of successful low-cost airlines in the world market and reveals the distinctive features of this business model, which should be taken into account when building business processes by new enterprises in the industry of passenger air 
transportation of Russia or by the operating airline "Pobeda" in order to expand its destinations and achieve successful performance indicators, in particular, passenger flow and profit.

\section{Discussions}

In order to create a favorable climate for the performance of the discount airline in the territory of the Russian Federation, it is also necessary to conduct research and identify the main target segment of consumers of low-cost airlines, to attract business passengers as the most profitable segment of consumers, and introduce a business pass. Studies of the demographic characteristics of the Russian population and the calculation of the coefficient of aviation mobility of Russians will make it possible to carry out a comparative analysis with the indicator of this coefficient in Europe and America and take into account the obtained data when forming the business model of the Russian discount airline.

\section{Conclusion}

Summarizing, it should be noted that the productive performance of the discount airline in the Russian Federation is possible under conditions of political support and infrastructure development and taking into account the length of the territory of Russia in accordance with the transport strategy of the Russian Federation until 2030 ("Transport Strategy of the Russian Federation until 2030") [13]. The goals set in the Transport Strategy, namely to achieve a transport mobility factor of unit value, can be solved not by increasing the number of frequent fliers, but by raising the level of welfare and purchasing power of the population, as well as by discount subsidizing air transportation both at the federal level, and subjects of the federation, the priority development of low-cost airlines, regional air transportation and ground-based airfield infrastructure (Rudnev, 2010) [14]. The growing popularity of air transport and marketing tools, which have not been used by airlines in the Russian market before, also create favorable conditions for the development of low-cost destinations.

In conclusion, the authors note that the development of human transport options and means of communication are moving to a new stage of development called "death of distance". The modern consumer does not become a collector of material wealth, he is a "collector of experience", and it certainly leads to an increase in mobility of the population, becoming a new factor in stratification of the world space. The availability of vehicles forms a new way of life, dividing society into privileged and non-privileged, thereby "highlighting" and creating a niche for the development of successful performance of low-cost airlines in the economic space of Russia.

\section{References}

[1]. Veselova, E.V. (2015). The competitiveness of Russian airlines in the international markets for passenger air travel. Abstract of the dissertation of the candidate of economic sciences. Financial University under the Government of the Russian Federation: Moscow. Retrieved from: Russian State Library https://search.rsl.ru/ru/record/01005568353.

[2]. Fedyashova, I.G. (2006). Marketing research of airport services. Scientific Bulletin of MGTU GA, series Management, Economics, Finance, № 106. Retrieved from Scientific Electronic Library "Kiberlinika" https://cyberleninka.ru/article/v/marketingovyeisslelovaniya-aeroportovyh-uslug.

[3]. Belavintsev, I.A. (2012). State support of passenger traffic on domestic Russian routes. Scientific Bulletin of MSTU GA, No. 181, pp. 3034. Retrieved from Scientific Electronic Library "Kiberlinika"

https://cyberleninka.ru/article/v/gosudarstvennay a-podderzhka-passazhirskih-perevozok-navnutrirossiyskih-vozdushnyh-liniyah.

[4]. Klyagin, A.V. (2006). Logistical service in the activity of an economic high school: the author's abstract of the dissertation and the candidate of economic sciences. Russian Economic University named after G.V. Plekhanova: Moscow. Retrieved from: Russian State Library https://search.rsl.ru/ru/record/01003272015.

[5]. Yaguzinskaya, I.Yu. (2011). Research of the system for assessing the level of logistics service in car dealerships. Bulletin of the SSTU, № 4 (60), pp. 242-246. Retrieved from Scientific Electronic Library "Kiberlinika": https://cyberleninka.ru/article/v/issledovaniesistemy-otsenki-urovnya-logisticheskogoservisa-v-avtosalonah.

[6]. Hazledine, T. (2015). PRICE DISCRIMINATION, MERGER POLICY, AND THE COMPETITIVE CONSTRAINT OF LOWVALUE CUSTOMERS IN AIRLINE MARKETS. Journal of Competition Law \& Economics, Volume 11, Issue 4, pp. 975-998, retrieved from: https://doi.org/10.1093/joclec/nhv031.

[7]. Ching-Cheng Chao, Taih-Cherng Lirn, KuoChung Shang (2013). Market segmentation of airline cargo transport. The Service Industries Journal, Volume 33, Issue 15-16, pp.1672-1685. https://doi.org/10.1080/02642069.2011.638920.

Retrieved from: 
https://www.tandfonline.com/doi/abs/10.1080/02 642069.2011.638920.

[8]. Young Dae Ko (2016). An airline's management strategies in a competitive air transport market. Journal of Air Transport Management. Volume 50 , pp. $53-$

61. https://doi.org/10.1016/j.jairtraman.2015.10. 005. Retrieved from https:/www.sciencedirect.com/science/article/ab s/pii/S0969699715001210.

[9]. Information Agency of RBC. (2016). Low-cost airline "Pobeda" was released in profit after a year of flight. Retrieved from http://www.rbc.ru/business/04/03/2016/56d8d73f 9a794759b352ebf5

[10]. Federal Air Transport Agency of the Russian Federation. Rosaviation. (2016). Retrieved from http://favt.ru/public/mate rials//9/b/2/3/3/9b233129e79466ab0daf977c98d9 2ee6.pdf.

[11]. The Federal Law "On Amendments to Article 56 of the Air Code of the Russian Federation and
Article 14 of the Federal Law" On the Legal Status of Foreign Citizens in the Russian Federation "of April 20, 2014 No. 73-FZ (last version).

[12]. S7 Airlines. (2016). Retrieved from https://www.s7.ru/home/about/s7airlines.dot\#informaciya-o-strahovschike-ideystvuyuschem-dogovore-strahovaniyagrajdanskoy-otvetstvennosti

[13]. Transport Strategy of the Russian Federation until 2030. The Russian Federation Government Resolution № 1734-p dated 22.11.2008. (2016). Retrieved from http://rosavtodor.ru/storage/b/2014/03/23/strategi a.pdf.

[14]. Rudnev, S. (2010). Aviation mobility of Russia's population. Business Aviation Portal. Retrieved from http://www.ato.ru/content/aviacionnayapodvizhnost-naseleniya-rossii. 